\section{A comparison of ranitidine, droperidol or placebo in the prevention of nausea and vomiting after hysterectomy}

Dimitri Cozanitis MBCHB MD, Riitta Asantila MD PHD, Pirkko Eklund MD, Markku Paloheimo MD PHD

\begin{abstract}
Purpose: The effect of ranitidine on postoperative nausea and vomiting (PONV) was assessed when compared with droperidol and with placebo.
\end{abstract}

Methods: Three groups of sixty patients were studied in a double-blind randomized manner. The first group received ranitidine tablets $300 \mathrm{mg}$ on the night before and on the following morning, one hour before induction of anaesthesia. Thirty minutes before surgery ended they were given isotonic saline $0.3 \mathrm{ml} \mathrm{iv}$. The second group had placebo in place of ranitidine while before the operation ended, droperidol $0.75 \mathrm{mg}(0.3 \mathrm{ml})$ was injected. The third group received placebos rather than the study drugs. The immediate two-hour postoperative recovery room period and that on the ward were evaluated until the next morning. PONV information was igathered from complaints by the patients and from direct questioning by the nursing staff. Droperidol $0.75 \mathrm{mg}$ iv served as the "rescue drug." Results: Less PONV occurred in patients who received antiemetics than those given placebo: recovery room, $P=0.0109$; ward, $P=0.007$. Droperidol better suppressed PONV in the recovery room $(P=0.005)$ with no statistical significance seen between ranitidine and placebo. On the ward, both antiemetics were more effective than placebo (ranitidine, $P=$ 0.01 ; droperidol, $P=0.003$ ). "Rescue drug" requirements throughout the study periods were not statistically significant. Conclusion: Although both anti-emetics were associated with a smaller incidence of PONV than was placebo, droperidol was superior to ranitidine in preventing sickness during the

\section{Key words}

ANAESTHESIA: gynaecological;

PHARMACOLOGY: droperidol, ranitidine;

VOMITING: anti-emetics, incidence, postoperative.

From the Departments of Anaesthesia, Helsinki University, and Helsinki Maternity Hospital, Helsinki, Finland.

Address correspondence to: Dr. D.A. Cozanitis, Pindarou 16, 10673 Athens, Greece.

Accepted for publication 13th September, 1995. immediate postoperative period. The need for the "rescue drug" was similar in all groups.

Objectif: Comparer l'effet de la ranitidine sur les nausées et vomissements postopératoires à celui du dropéridol et d'un placebo.

Méthodes: Cette étude randomisée et en double aveugle portait sur trois groupes de 60 patients. Le premier groupe a reçu de la ranitidine en tablette $300 \mathrm{mg}$ la veille et le matin de l'intervention, une heure avant l'induction de l'anesthésie. Trente minutes avant la fin de l'intervention. ses membres ont reçu $0,3 \mathrm{ml}$ iv de sol. physiologique isotonique. Le deuxième groupe a reçu un placebo au lieu de la ranitidine et avant la fin de l'intervention, du dropéridol $0,75 \mathrm{mg}(0,3 \mathrm{ml})$ iv. Le troisième groupe n'a reçu que du placebo. L'évaluation a été effectuée à la salle de réveil pendant les deux heures qui ont suivi l'intervention et, dans le service, jusqu'au lendemain matin. Les renseignement sur les nausées et vomissements provenaient des plaintes spontanées et des questions du personnel infirmier. Le médicament de sauvetage était dropéridol $0,75 \mathrm{mg}$ iv.

Résultats: Les nausées et vomissements ont été moins fréquents chez les patients qui avaient reçu des antiémétiques plutôt qu'un placebo: à la salle de réveil, $P=0,0109$; dans le service, $P=0,007$. Le dropéridol protège mieux des nausées et des vomissements en salle de réveil $(P=0,005)$ et il n'y pas eu de différence entre la ranitidine et le placebo. Dans le service, les deur antiémétiques ont été plus efficaces que le placebo (ranitidine, $P=0,01$; dropéridol, $P=0.003$ ). Les besoins en médicament de sauvetage n'ont pas différé.

Conclusion: Bien que les deux antiémétiques aient été associés à une incidence plus faible de nausées et vomissements, le dropéridol a été supérieur à la ranitidine pendant la période postopératoire immédiate. Les besoins en médicaments de sauvetage ont été les mêmes dans tous les groupes.

Although $5-\mathrm{HT}_{3}$ receptor antagonist drugs such as ondansetron may be effective anti-emetics after anaes- 
thesia, ${ }^{1,2}$ they are very expensive. The anti-emetic efficacy of ranitidine, ${ }^{3.4}$ an $\mathrm{H}_{2}$-receptor antagonist, has not been thoroughly addressed. Ranitidine increases the $\mathrm{pH}$ of gastric juice and diminishes its volume. Thus, it was decided to evaluate the influence of ranitidine on postoperative nausea and/or vomiting (PONV) after hysterectomy and to compare it with droperidol which is alrendy established as an anti-emetic, ${ }^{5,6}$ and with a placebo.

\section{Methods}

Following ethical committee and patient oral consent, three groups of 60 Finnish patients about to undergo abdominal hysterectomy were entered into the randomized, double-blind study. The first group was given ranilidine $300 \mathrm{mg}$ po on the evening prior to surgery and again on the following morning. Approximately $30 \mathrm{~min}$ before the end of surgery, these patients received isotonic saline $0.3 \mathrm{ml}$ iv. The second group received placebo tablets on the evening before and on the morning of surgery. About $30 \mathrm{~min}$ before surgery ended, droperidol $0.75 \mathrm{mg}(0.3 \mathrm{ml})$ was injected iv. Patients in the third group served as control; they were given placebo tablets on the evening and morning while before the operation ended, saline $0.3 \mathrm{ml}$ was injected $i v$.

On the evening before surgery, all patients received temazepam tablets $20 \mathrm{mg}$ along with the randomized study drug. On the following morning, diazepam $10 \mathrm{mg}$ and the study drug were given $p o$, about one hour before the patient was taken to the operating theatre. Following glycopyrrolate $0.2 \mathrm{mg}$ and alcuronium $2-3 \mathrm{mg}$, anaesthesia was induced with fentanyl $0.1 \mathrm{mg}$ and thiopentone. Tracheal intubation was facilitated using succinylcholine. All drugs were injected into an intravenous infusion of Ringer's acetate solution. Anaesthesia was maintained with nitrous oxide/oxygen (2:1) and isoflurane $0.3-1 \%$ (inspired). Fentanyl $0.05-0.1 \mathrm{mg}$ was given as needed and alcuronium served as the muscle relaxant. Neostigmine $2 \mathrm{mg}$ and glycopyrrolate $0.4 \mathrm{mg}$ were given when surgery ended to antagonize the remaining neuromuscular blockade. As is standard practice in this hospital, diclofenac $75 \mathrm{mg}$ was given via a slow intravenous infusion to every patient in the recovery room and repeated when she was returned to her ward. On average, 2.51 were infused to each patient in the form of Ringer's acetate and isotonic glucose solutions during the study period.

The amount of fentanyl that each patient received was recorded. Postoperative pain was treated with oxycodone 3-4 $\mathrm{mg}$ iv and $8-10 \mathrm{mg}$ im respectively in the recovery room and on the ward; the total amounts being recorded.

Droperidol $0.75 \mathrm{mg}$ iv was used as the "rescue drug"
TABLE I Details of the patients, duration of anacsthesia and amounts of opioids given to the study groups. Means (SD)

\begin{tabular}{llll}
\hline & Group & & \\
\cline { 2 - 4 } & $\begin{array}{l}\text { Ranitidine } \\
n=60\end{array}$ & $\begin{array}{l}\text { Droperidol } \\
n=60\end{array}$ & $\begin{array}{l}\text { Placebo } \\
n=60\end{array}$ \\
\hline Age & 45.7 & 46.2 & 46.8 \\
(yr) & $(6.61)$ & $(6.54)$ & $(7.24)$ \\
Wcight & 65.6 & 68.1 & 66.6 \\
(cm) & $(8.89)$ & $(11.69)$ & $(12.76)$ \\
Height & 163 & 164 & 163 \\
(cm) & $(5)$ & $(5)$ & $(5)$ \\
Anacsthesia & 108 & 110 & 109 \\
(min) & $(29)$ & $(33)$ & $(29)$ \\
Fentany! & 0.29 & 0.29 & 0.28 \\
(mg) & $(0.061)$ & $(0.069)$ & $(0.068)$ \\
Oxycodonc* & 13.2 & 12.5 & 12.5 \\
(mg) & $(4.28)$ & $(4.38)$ & $(4.05)$ \\
Oxycodonc $\dagger$ & 44.7 & 45.4 & 44.2 \\
(mg) & $(10.12)$ & $(12.01)$ & $(9.59)$ \\
\hline
\end{tabular}

*Recovery room.

+Ward.

when and if the patient was nauseated for more than ten minutes and/or if she vomited more than once. Throughout the trial period, the incidence of PONV was recorded by the nurses from the patients' spontaneous complaints and from information gained by direct questioning. The final questioning was done on the morning after the hysterectomy.

The data were analyzed using ANOVA one-way analysis of variance and by the chi-squared test. ${ }^{7}$ The Bonferroni correction test was applied for truly significant differences. Statistical significance was considered at a $P<0.05$. PONV was defined as nausea and/or vomiting and the occurrence of either symptom was taken as the definitive end-point. ${ }^{8}$

\section{Results}

The details of the patients, duration of anaesthesia and the total amounts of analgesic drugs given (Table I) were comparable. Seventy-five, 88 , and $65 \%$, respectively, of patients in the ranitidine, droperidol and control groups had operations free from PONV.

The incidence of PONV in patients receiving an antiemetic drug in the recovery room was significantly smaller $(P=0.0109)$ than those having placebo (Table II). Such also was the case when the patients were returned to their wards $\cdot(P=0.007)$.

The effectiveness of preventing PONV in the recovery room (using repeated comparisons, i.e., Bonferroni's correction) was significantly greater with droperidol ( $n$ $=53)$ than with placebo $(n=39,3 P=0.015)$. On the other hand, ranitidine $(n=45)$ when compared to place- 
TABLE II Incidence of PONV and need for the rescue drug among the study groups

\begin{tabular}{|c|c|c|c|}
\hline & \multicolumn{3}{|l|}{ Group } \\
\hline & $\begin{array}{l}\text { Ranitidine } \\
n=60\end{array}$ & $\begin{array}{l}\text { Droperidol } \\
n=60\end{array}$ & $\begin{array}{l}\text { Placebo } \\
n=60\end{array}$ \\
\hline \multicolumn{4}{|c|}{ Incidence of PONV in treated and control patients } \\
\hline \multicolumn{4}{|c|}{ Recovery room } \\
\hline No PONV & & & 39 \\
\hline PONV & & & 21 \\
\hline \multicolumn{4}{|l|}{ Ward } \\
\hline No PONV & & & 20 \\
\hline PONV & & & 40 \\
\hline \multicolumn{4}{|c|}{ Need for rescue drug, droperidol } \\
\hline \multicolumn{4}{|c|}{ Recovery room } \\
\hline Nceded & 11 & 4 & 13 \\
\hline Not necded & 49 & 56 & 47 \\
\hline \multicolumn{4}{|l|}{ Ward } \\
\hline Needed & 8 & 7 & 12 \\
\hline Not needed & 52 & 53 & 48 \\
\hline
\end{tabular}

bo $(n=39)$ was ineffective, $P=0.319$. On the ward, however, both ranitidine $(n=37)$ and droperidol $(n=$ 39) were respectively more effective $(3 P=0.010$ and $3 P=0.003)$ than placebo $(n=20)$.

Neither in the recovery room nor on the ward was any statistically significant difference found among the study groups regarding the need for the rescue drug, droperidol (Table II).

\section{Discussion}

In this comparative study of ranitidine and droperidol with saline serving as control, the main finding was that in the immediate two-hour postoperative period, droperidol was superior in preventing PONV. However, when the patients returned to the ward, the incidence of PONV in the ranitidine and droperidol groups did not differ but both were better than the saline-control patients.

Factors such as ethnic background, sex, age, surgical procedure, duration of anaesthesia and total amounts of anaesthetic agents including opioids and intravenous fluid volumes were standardised in the current study. The fact that all anaesthetics were administered by senior staff could have resulted in a smaller incidence of PONV. ${ }^{9}$ Nevertheless, certain factors that may have influenced the outcome of the trial, e.g., the period of the patient's menstrual cycle ${ }^{10}$ and past history of nausea and vomiting " were not taken into account.

Droperidol $0.75 \mathrm{mg}$ (selected according to daily clini- cal practice) $30 \mathrm{~min}$ before the end of surgery provided effective control against PONV in the first two hours after hysterectomy. No obvious undesirable side effects, e.g., lowering of blood pressure, sedation, extrapyramidal reactions were noted in any patient.

The moving or transporting of a patient following surgery may be associated with sickness. ${ }^{12}$ Thus, this may be a reason for the increase in the incidence of sickness when the patients returned to the ward. It is possible that the effectiveness of the small dose of droperidol may have lapsed. Perhaps, therefore, a second dose of this drug, if given some minutes before the patients were transported, could have reduced the incidence of PONV in them and this could be determined in future studies.

The earlier reports of ranitidine being effective in the control of postoperative sickness ${ }^{3,4}$ were only partially confirmed. In these studies the second dose of ranitidine was given two to three hours before the start of anaesthesia to out-patients in whom gastric suctioning was applied at the end of surgery. The patients received isoflurane alone or together with a single minimal dose of fentanyl $\left(1 \mu \mathrm{g} \cdot \mathrm{kg}^{-1} i v\right)$.

In this study, droperidol was associated with less sickness than in patients who had received ranitidine. The low cost of droperidol $(0.75 \mathrm{mg}=0.20 \mathrm{US} \$)$ deserves consideration in its use. This is especially so in light of a recent study which found droperidol and the 5HT receptor ondansetron to be equi-effective in suppressing postoperative sickness. ${ }^{13}$

In conclusion, when compared with placebo, both ranitidine and droperidol reduced the incidence of PONV. During the immediate postoperative period, droperidol provided better control of PONV than did ranitidine. Both anti-emetics were more effective than placebo during the period when patients were back on the ward. The need for the rescue drug did not differ among the groups.

\section{Acknowledgements}

Thanks are due to the nurses who recorded the data and to Drs. Ulla Tarkkanen, Irma Jousela and Heli Latvala for their kind help. Glaxo (UK) kindly supplied the ranitidine (Zantac) and other study materials and supported the trial.

\section{References}

1 Leeser J, Lip H. Prevention of postoperative nausea and vomiting using ondansetron, a new, selective, $5-\mathrm{HT}_{3}$ receptor antagonist. Anesth Analg 1991; 72: 751-5.

2 Dupeyron JP, Conseiller $C$, Levarlet $M$, et al. The effect of oral ondansetron in the prevention of postoperative nausea and vomiting after major gynaecological surgery per- 
formed under general anaesthesia. Anaesthesia 1993; 48:

214-8.

3 Kraynack BJ, Bates $M F$. Ranitidine reduces nausea and vomiting after thiopental-isoflurane anesthesia.

Anesthesiology 1990; 73: A42.

4 Kraynack BJ, Bates $M F$, Gintautas $J$. Antiemetic efficacy of ranitidine, metoclopramide and gastric suctioning in outpatient laparoscopy. Anesth Analg 1990; 70: S218.

5 Nikki $P$, Pohjola S. Nausea and vomiting after ocular surgery. Acta Ophthalmol 1972; 50: 525-31.

6 Korttila K, Kauste A, Auvinen J. Comparison of domperidone, droperidol, and metoclopramide in the prevention and treatment of nausea and vomiting after balanced general anesthesia. Anesth Analg 1979; 58: 396-400.

7 Bradford Hill A. Principles of Medical Statistics. 8th ed. New York: Oxford University Press, 1976; 162-74.

8 Korttila $K$. The study of postoperative nausea and vomiting. Br J Anaesth 1992; 20S-23S.

9 Hovorka J, Kortila $K$, Erkola $O$. The experience of the person ventilating the lungs does influence postoperative nausea and vomiting. Acta Anacsthesiol Scand 1990; 34: 203-5.

10 Honkavaara P, Lehtinen A-M, Hovorka J, Korttila K. Nausea and vomiting after gynaecological laparoscopy depends upon the phase of the menstrual cycle. Can J Anaesth 1991; 38: 876-9.

11 Burtles $R$, Peckett BW. Postoperative vomiting: some factors affecting its incidence. $\mathrm{Br} J$ Anaesth 1957; 29: 114-23.

12 Kamath B, Curran J, Hawkey C, et al. Anaesthesia, movement and emesis. Br J Anaesth 1990; 64: 728-30.

13 Gan $T J$, Collis R, Hetreed $M$. Ondansetron, droperidol and saline for prevention of nausea and vomiting after major orthopaedic surgery. A double-blind controlled study. Br J Anaesth 1993; 71: 768P. 